\title{
Bovine rabies in Rio Grande do Sul: positivity rates, geographical distribution, and seasonal occurrence
}

\author{
Raiva bovina no Rio Grande do Sul: taxas de positividade, \\ distribuição geográfica e ocorrência sazonal
}

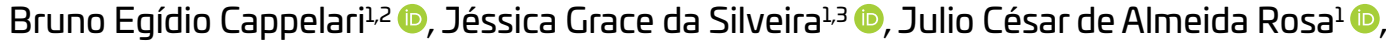 \\ José Carlos Ferreira ${ }^{1}$ (i), Giovana Dantas ${ }^{1,4^{*}}$ (1)
}

\begin{abstract}
Rabies is a zoonotic disease characterized by acute viral encephalitis. It is almost $100 \%$ fatal for infected animals. While cases of human rabies have still been registered in Brazil, in the state of Rio Grande do Sul rabies is considered a controlled disease in urban areas. However, the transmission of bovine rabies - which has been largely associated with the Desmodus rotundus bat - is endemic. Additionally, there are estimates that only $10 \%$ of rabies cases are reported. Therefore, this study aimed to describe the positivity rates, geographical distribution, and seasonal occurrence of bovine rabies in RS, as well as the sampling practices in rabies surveillance. Using samples submitted for laboratory diagnosis from 2016 to 2019, we conducted a retrospective study of the sample results, positivity rates, and seasonal occurrence of rabies in cattle. Throughout these four years, less than a third of state municipalities sent samples for diagnosis, suggesting that the occurrence of rabies might still be underestimated in non-sampled areas. A higher number of rabies cases were reported in 2019, a year in which the most diagnosed samples and the highest positivity percentages were recorded. However, the case numbers registered between 2016 and 2019 were not significantly different. We found that the summer and autumn months presented statistically different positivity rates. Besides this, we did not find any positive $D$. rotundus samples, despite the positivity rates for bovine rabies. Active surveillance, especially of bat populations and under-sampled regions, must be strengthened to correctly estimate the impact of rabies.
\end{abstract}

KEYWORDS: Rabies surveillance; Seasonality; Bat rabies; Spatial analysis.

RESUMO: A raiva é uma zoonose caracterizada por uma encefalite viral aguda, sendo fatal em quase $100 \%$ das infecçôes em animais. Ainda que casos humanos ainda sejam registrados no Brasil, no Rio Grande do Sul (RS) a raiva é considerada uma doença controlada em áreas urbanas. Entretanto, a transmissão da raiva bovina, que tem sido frequentemente associada ao morcego Desmodus rotundus, é endêmica. Ademais, estima-se que apenas $10 \%$ de todos os casos de raiva são notificados. Assim, este estudo buscou descrever as taxas de positividade, distribuição geográfica e a ocorrência sazonal da raiva bovina no RS, bem como as práticas de amostragem na vigilância da raiva. Utilizando amostras submetidas a diagnóstico laboratorial de 2016 a 2019, foi realizado um estudo retrospectivo dos resultados laboratoriais, taxas de positividade e ocorrência sazonal da raiva em bovinos. Ao longo dos quatro anos, menos de um terço dos municípios enviou amostras para diagnóstico, sugerindo que a ocorrência da raiva pode ainda ser subestimada em áreas sem amostragem. O maior número de casos de raiva foi notificado em 2019, ano com o maior número de amostras enviadas para diagnóstico e maior taxa de positividade. Apesar disso, o número de casos registrados entre 2016 e 2019 não foram significativamente diferentes. Foram encontrados valores estatisticamente diferentes nas taxas de positividade dos meses de verão e outono. Além disso, não foram detectadas amostras positivas de D. rotundus, apesar das taxas de positividade da raiva bovina. A vigilância ativa, especialmente das populaçóes de morcegos e regiōes não amostradas, deve ser fortalecida para mensurar adequadamente o impacto da raiva.

PALAVRAS-CHAVE: Vigilância da raiva; Sazonalidade; Raiva em morcegos; Análise espacial.

\footnotetext{
${ }^{1}$ Laboratório de Virologia, Instituto de Pesquisas Veterinárias Desidério Finamor, Eldorado do Sul/RS, Brasil

2 Universidade do Vale do Rio dos Sinos, São Leopoldo/RS, Brasil

${ }^{3}$ Centro Universitário Ritter dos Reis, Porto Alegre/RS, Brasil

${ }^{4}$ Programa de Pós-graduação em Saúde Animal do Instituto de Pesquisas Veterinárias Desidério Finamor

*Corresponding author: giovana-araujo@agricultura.rs.gov.br

Received: 16/12/2020. Accepted: 09/04/2021
} 


\section{INTRODUCTION}

Rabies is a zoonotic disease characterized by acute viral encephalitis. It is almost $100 \%$ fatal for infected animals. Despite being well-known for centuries, the disease still poses a serious problem to public health, particularly in Asia and Africa (WHO, 2018). In the Americas, although cases of human rabies were reduced by $96 \%$ between 2005 and 2015, countries such as Bolivia, Mexico and Brazil have still not eradicated the disease (VELASCO-VILLA et al., 2017).

Studies have addressed the occurrence of human rabies in Brazil, mainly in the Amazon and Northeast regions (ROSA et al., 2006; FERNANDES et al., 2013; VARGAS; ROMANO; MERCHÁN-HAMANN, 2019). However, in 2019 the state of Santa Catarina registered the first human death caused by rabies since 1981 . The subject was a 58 -year-old woman who had been bitten by a cat (SANTA CATARINA, 2019). In 2020, the death of a teenager infected by a bat led to an epidemiological alert in Rio de Janeiro, a state that had been free from human rabies since 2006 (RIO DE JANEIRO, 2020).

In the state of Rio Grande do Sul (RS), the last human death caused by rabies was registered in 1981. Since it had been considered a controlled disease in urban areas, the most recent cases of canine and feline rabies (in 2007 and 2013) have been attributed to non-hematophagous bats and accidental transmission (TEIXEIRA et al., 2008). Therefore, the state of RS has not maintained an active vaccination program for domestic animals since 1996 (CENTRO ESTADUAL DE VIGILÂNCIA EM SAÚDE (CEVS), 2020; WADA; ROCHA; MAIA-ELKHOURY, 2011).

However, bovine rabies is endemic. It continues to cause economic losses and is still a risk factor for public health (RODENBUSCH et al., 2016). Results from the Brazilian institute that coordinates national geographic and statistical data (Instituto Brasileiro de Geografia e Estatística - IBGE) show that the state of RS has the seventh-largest bovine population in Brazil (IBGE, 2018), with an average of approximately 12.6 million heads counted between 2016 and 2020 (RIO GRANDE DO SUL, 2020). Herd vaccination is not mandatory by state law, although nearly $90 \%$ of all positive sample results come from cattle (TEIXEIRA et al. 2008).

It is estimated that only one in ten cases of herbivore rabies is reported (KOTAIT et al., 1998). Under-reporting leads to lower official numbers, impacts statistical data, and prevents rabies eradication (SANTOS et al., 2016; RODRIGUES et al., 2018; DOGNANI et al., 2016; RIBEIRO et al., 2018). This also holds true for the state of RS (TEIXEIRA et al., 2008).

It is well known that herbivore rabies is caused primarily by the vampire bat, Desmodus rotundus. It usually carries a specific variant of the virus $(\mathrm{AgV} 3)$ that can be identified with molecular sequencing (WHO, 2018). Large population numbers make cattle the primary source of food for $D$. rotundus, whereas the occurrence of rabies is sporadic among horses, sheep, buffaloes, and other herbivores in RS (TEIXEIRA et al., 2008).

In 2019, there was an increase in the number of bovine samples that tested positive for rabies in RS. By May of that year, the number of registered bovine cases composed $82 \%$ of all bovine cases recorded in 2018. This caused the local state authority, Secretaria da Agricultura, Pecuária e Desenvolvimento Rural (SEAPDR), to issue a health alert (RIO GRANDE DO SUL, 2019). This study aimed to describe the positivity rates, geographical distribution, and seasonal occurrence of bovine rabies in 2019, as well as the sampling practices used in rabies surveillance.

\section{MATERIALS AND METHODS}

We conducted a retrospective study of the sample submissions and positive rabies rates in cattle in RS. From 2016 to 2019, samples were sent to the virology laboratory of the Instituto de Pesquisas Veterinárias Desidério Finamor (IPVDF) for a rabies diagnosis. This diagnosis was based on the results of the direct fluorescent antibody test, which was carried out as described by Dean, Abelseth, and Atanasiu (1996). Negative results were confirmed with the mouse inoculation test (MIT) (WHO, 2018). MIT use was approved by an ethics committee (CEUA, n. 24/19).

Samples were cataloged in Microsoft Excel $^{\circledR} 2007$ software, with the month of diagnosis, municipality of origin, and laboratory result. The number of submitted samples and positivity rates were calculated for each year, intermediate region (according to IBGE, 2017), and season. Summer was defined as the period from December to February, autumn from March to May, winter from June to August, and spring from September to November. To verify differences between the years and seasonal incidence, normality and ANOVA tests were performed with Past ${ }^{\circledR} 3.2$ software. ArcGis ${ }^{\circledast}$ software was used to create the maps.

\section{RESULTS AND DISCUSSION}

Bovine samples composed approximately $20 \%$ of all samples sent to the laboratory for rabies testing in RS (Figure 1A). In the period we studied, 2019 showed the highest number of tested bovine samples and the highest positivity rate (Figure 1B). Although several local media outlets, as well as the SEAPDR, acknowledged a higher number of bovine rabies cases in 2019, there was no significant difference among positivity rates in the period running from 2016 to 2019. However, it also became clear that, after receiving a positive result, health professionals often stopped sending the brain samples of other dying animals with similar clinical symptoms. Teixeira et al. (2008) previously reported that this is a common practice.

Using the standard form that is filled out to submit herbivore samples for laboratory diagnosis, professionals reported that animals from different properties presented similar but undiagnosed clinical manifestations leading to death. 


\section{Overall sample submission for a rabies laboratory diagnosis in RS, 2016-2019}

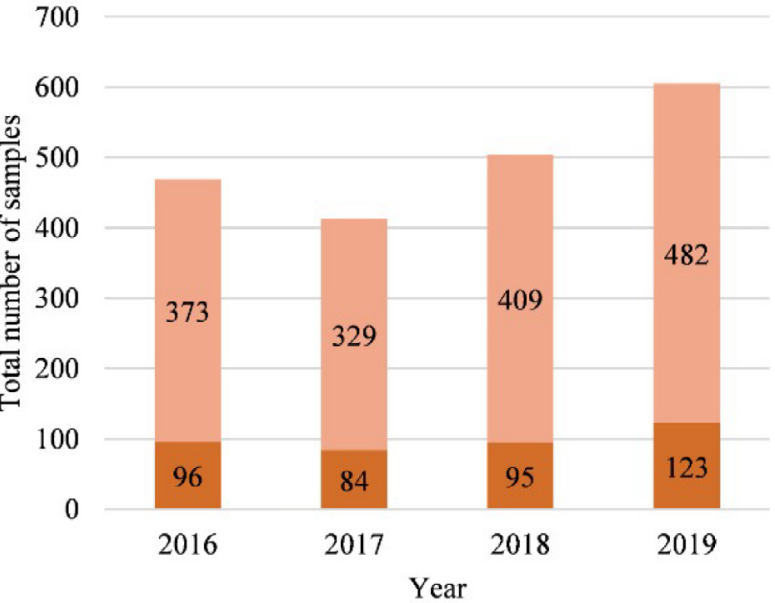

Bovine $\quad$ Other Species

\section{Bovine samples submitted for a rabies laboratory diagnosis in RS, 2016-2019}

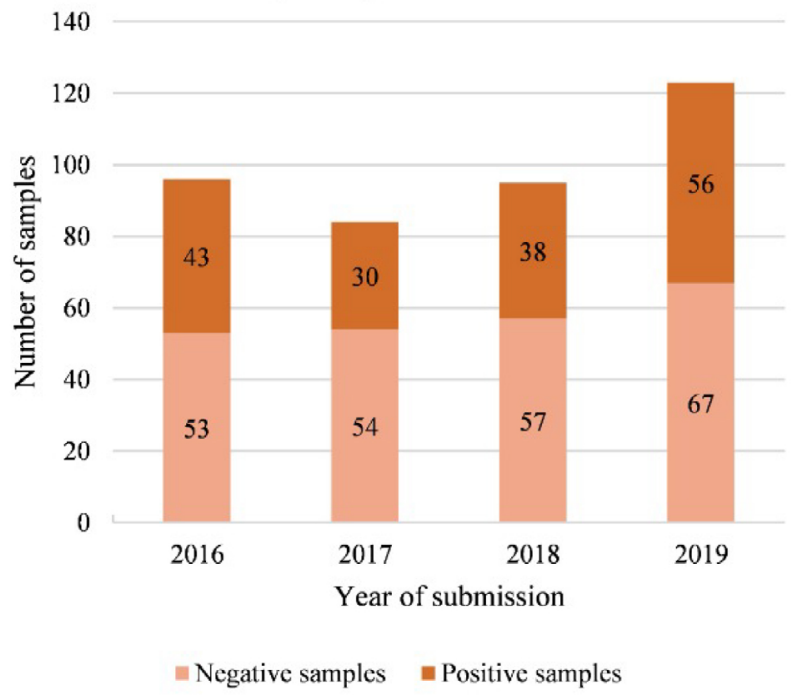

Figure 1. A. Overall sample submission for a laboratory diagnosis of rabies in Rio Grande do Sul from 2016 to 2019 . B. Number of sample submissions and positive bovine diagnoses of rabies in Rio Grande do Sul from 2016 to 2019.

Local media also covered the rabies occurrence in a municipality where over ten animals had died. However, only one sample was sent to the laboratory for diagnosis. The result was positive. Therefore, calculating the official number of deaths caused by rabies is affected by a lack of confirmation through laboratory diagnosis. This points to an underreporting of the disease.

Although 2019 was also the year with the highest number of municipalities submitting bovine samples, with at least one positive result (Figures 2-5), from 2016 to 2019 less than a third ( $\mathrm{n}=144,28.97 \%)$ of RS municipalities sent in bovine samples for a rabies diagnosis. Out of all 144 municipalities, only four $(2.78 \%)$ sent in bovine samples for each of the four years we studied. Nine $(6.25 \%)$ submitted bovine samples for three of the four years, $44(30.56 \%)$ sent in bovine samples for two of the four years, and 87 (60.42\%) sent in bovine samples only one year. Regarding positivity, 77 RS municipalities registered at least one positive rabies diagnosis. Sáo Lourenço do Sul, in the Pelotas region, was the only municipality that received a positive rabies diagnosis for each of the four years of our study. Fifteen municipalities (19.5\%) showed positive results in two of the four years and 61 municipalities $(79.2 \%)$ showed positive results for one year (Figure 6).

The intermediate regions of Porto Alegre and Santa Cruz do Sul - Lajeado showed the highest number of municipalities submitting bovine samples for a rabies diagnosis ( 53 and 27 municipalities, respectively). Proportionally, approximately $60 \%$ of the municipalities in Pelotas, Uruguaiana and Porto Alegre sent in at least one bovine sample that received a positive or negative laboratory diagnosis of rabies between
2016 and 2019. Meanwhile, the regions of Ijuí, Passo Fundo, Santa Maria, and Caxias do Sul showed the lowest percentages (Figure 7).

This is concerning because sampling practices relate to positivity rates: the more municipalities send in samples, the higher the number of diagnosed and positive samples (RODENBUSCH et al., 2016). Since regions and municipalities with more efficient surveillance had higher positivity rates, in non-sampled areas the occurrence of rabies in cattle might still be underestimated.

The metropolitan region of Porto Alegre showed the most bovine sample submissions for each year and it also had the highest number of positive bovine samples in 2017 and 2019. The region of Pelotas showed a decline in bovine sample submission after 2017, a trend also observed in the Santa Maria region after 2016. On the other hand, in 2019 we found an increase in the Passo Fundo region that translated into the second-highest number of positive bovine samples, alongside the Santa Cruz do Sul - Lajeado region (Figures 8 and 9).

Although cattle production is largely concentrated in the west and south regions of RS in the Pampa biome, as they are more suitable environments for livestock (IBGE, 2018), the west region of RS sent in fewer bovine samples for diagnosis in the early 2010s (RODENBUSCH et al., 2016). This is still true today. From 2016 to 2019, the mid-west regions of Santa Maria $(\mathrm{n}=23)$, Uruguaiana $(\mathrm{n}=13)$ and Ijuí $(\mathrm{n}=8)$ sent in the lowest overall number of bovine samples for diagnosis (Figure 10).

Regarding other findings, some studies have observed seasonality in rabies cases in Brazil. In Minas Gerais, there has 

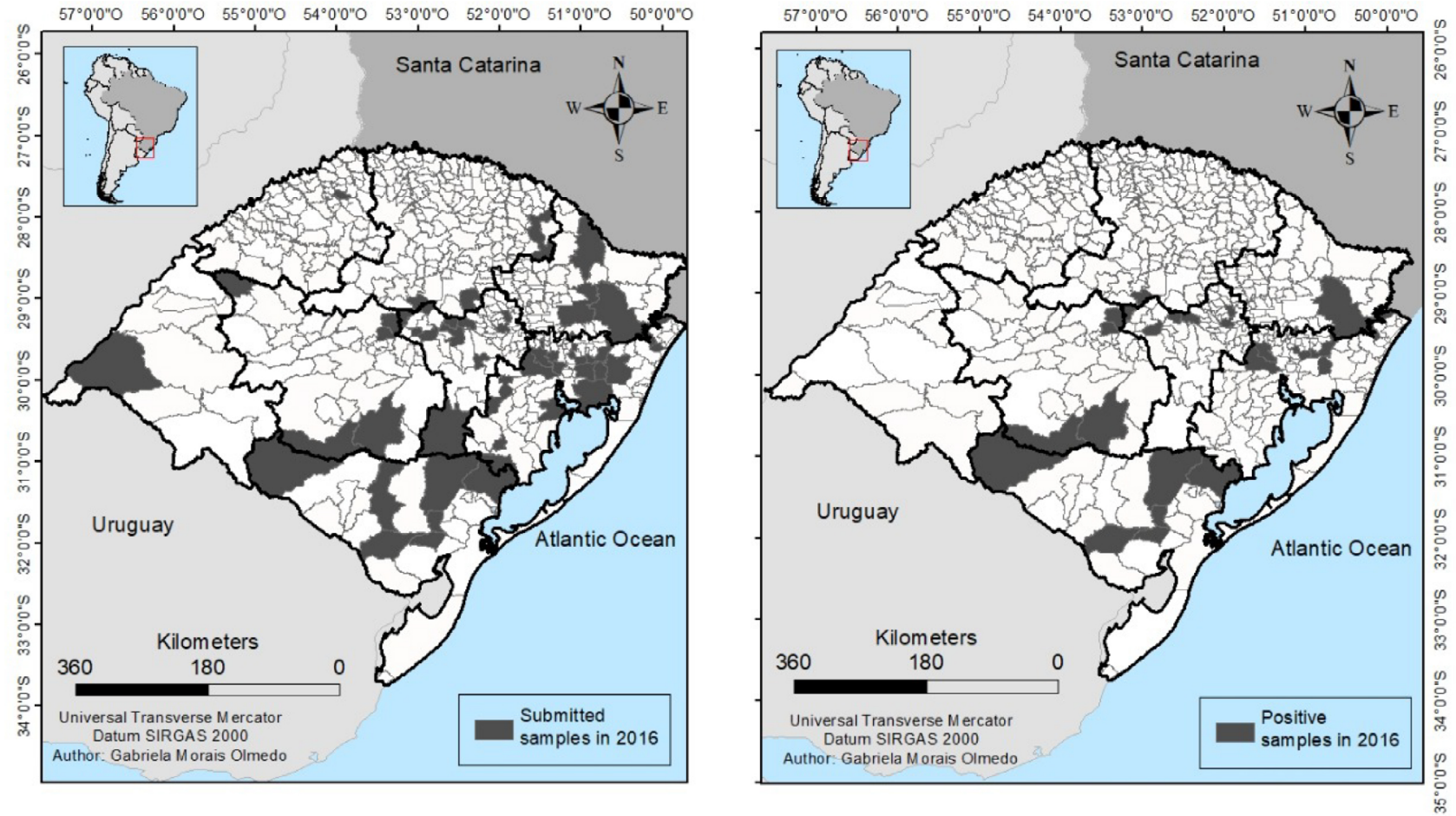

Figure 2. Municipalities that submitted at least one bovine sample for a laboratory diagnosis of rabies (left) and that received at least one positive result (right) in 2016.
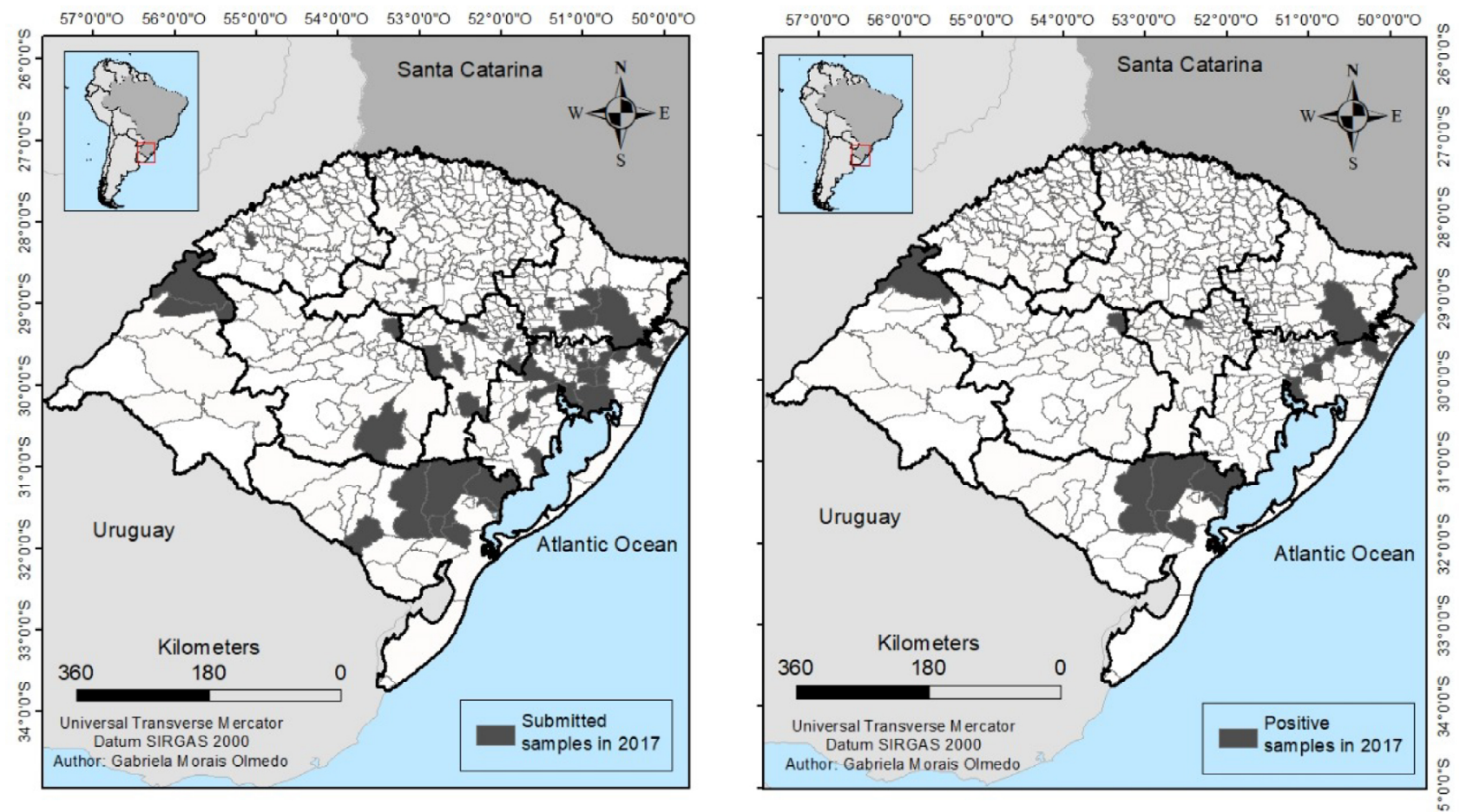

Figure 3. Municipalities that submitted at least one bovine sample for a laboratory diagnosis of rabies (left) and that received at least one positive result (right) in 2017.

been a higher incidence between April and August (SILVA et al., 2001). In Paraíba and Rio Grande do Norte, it is higher between March and August (LIMA et al., 2005) and in Mato Grosso do Sul, between March and April (RIBAS et al.,
2013). In RS, we noted seasonality between the summer and autumn months, from December to May. In this period there were statistically different positivity rates in cattle $(\mathrm{F}=9,139$; $\mathrm{p}<0.05$ ) (Figure 11). 

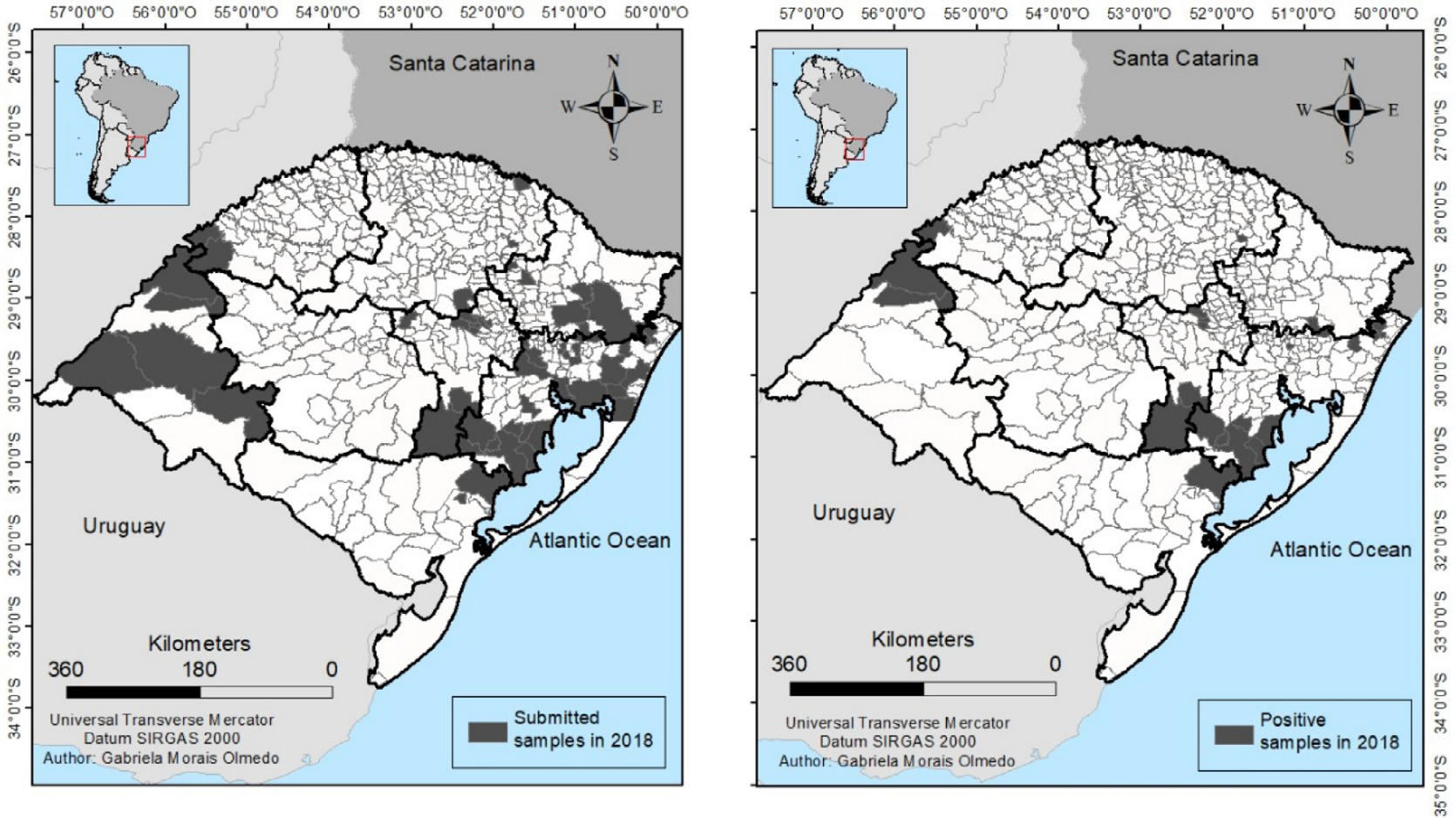

Figure 4. Municipalities that submitted at least one bovine sample for a laboratory diagnosis of rabies (left) and that received at least one positive result (right) in 2018.
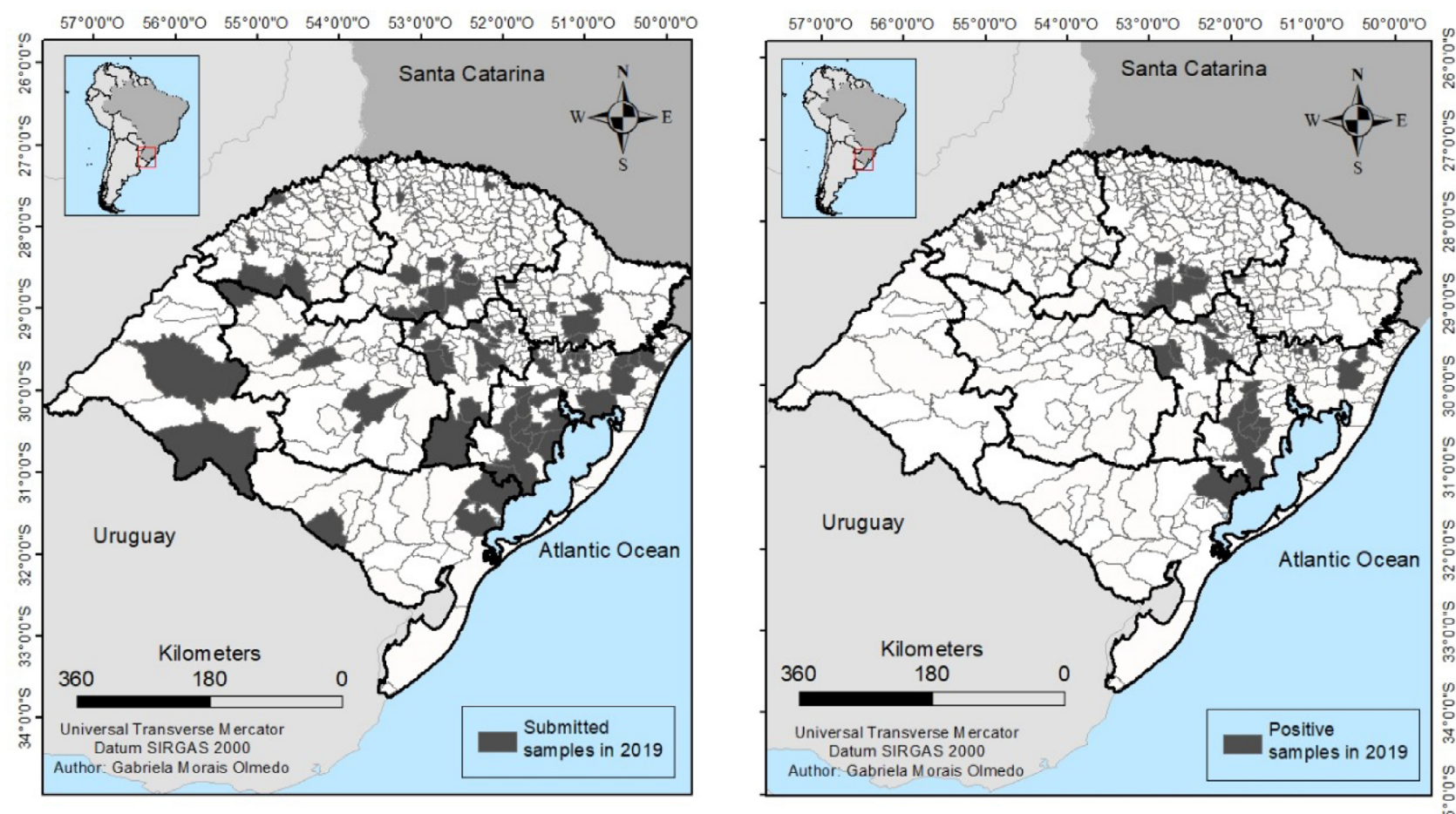

Figure 5. Municipalities that submitted at least one bovine sample for a rabies laboratory diagnosis (left) and that received at least one positive result (right) in 2019.

On the other hand, the spring months showed the lowest case numbers, possibly due to bat biology: after bat reproduction and infection in spring months, the virus incubates in both the bats and the bitten animals, leading to a higher number of cases in the summer and autumn months (MORI; LEMOS, 1998). Therefore, poor or no sampling of bat populations, especially the $D$. rotundus hematophagous species, is a limiting factor for analysis. Additionally, further studies 

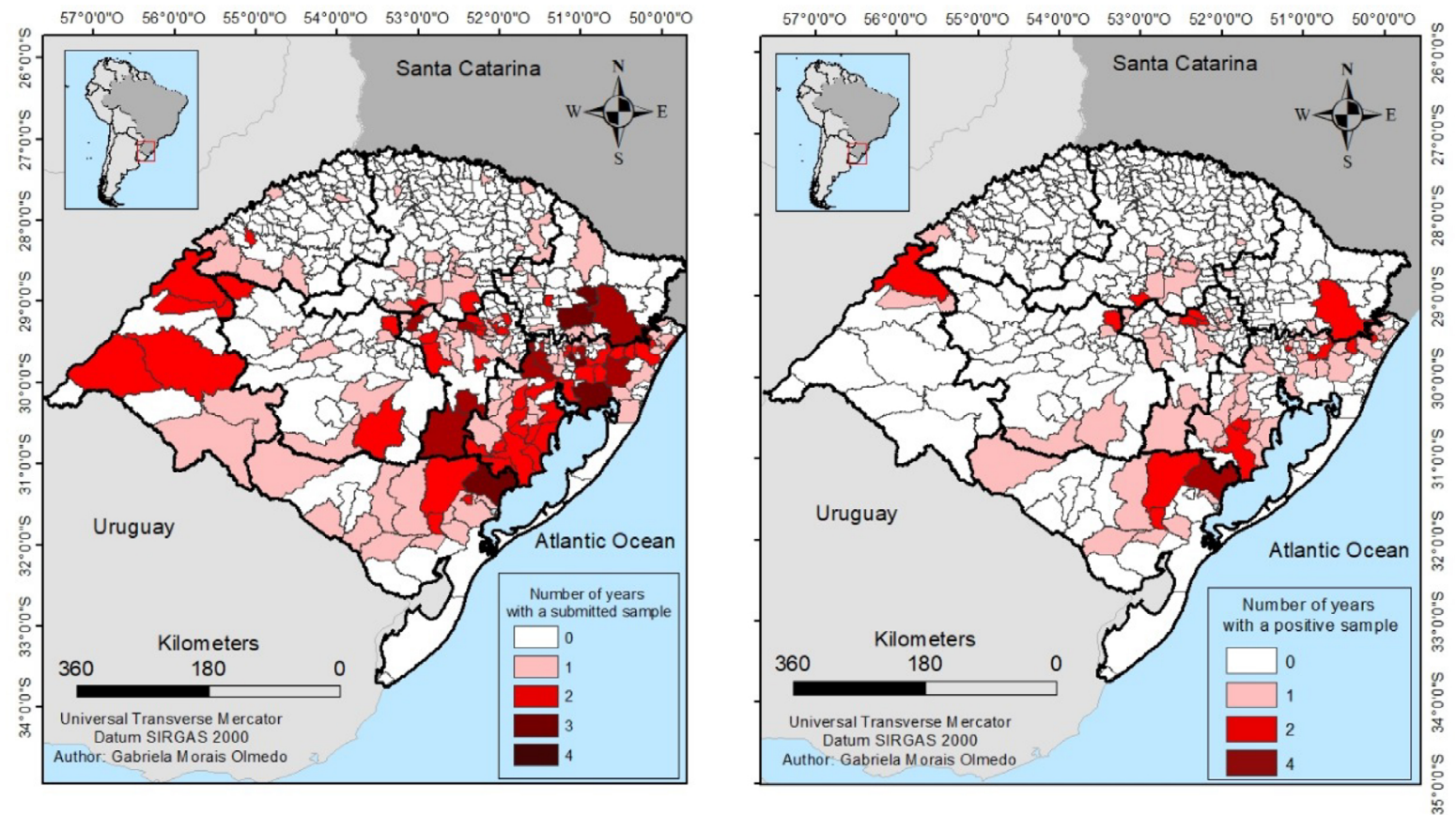

Figure 6. The number of years each municipality submitted at least one bovine sample for a laboratory diagnosis of rabies (left) and received at least one positive result (right).

Number of municipalities sampled for a rabies laboratory diagnosis in RS, 2016-2019

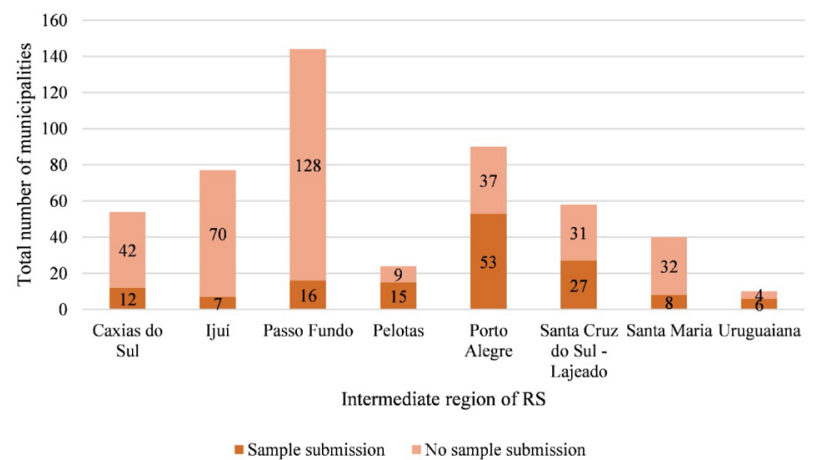

Figure 7. The number of municipalities with and without bovine sample submissions in each intermediate region of RS from 2016 to 2019.

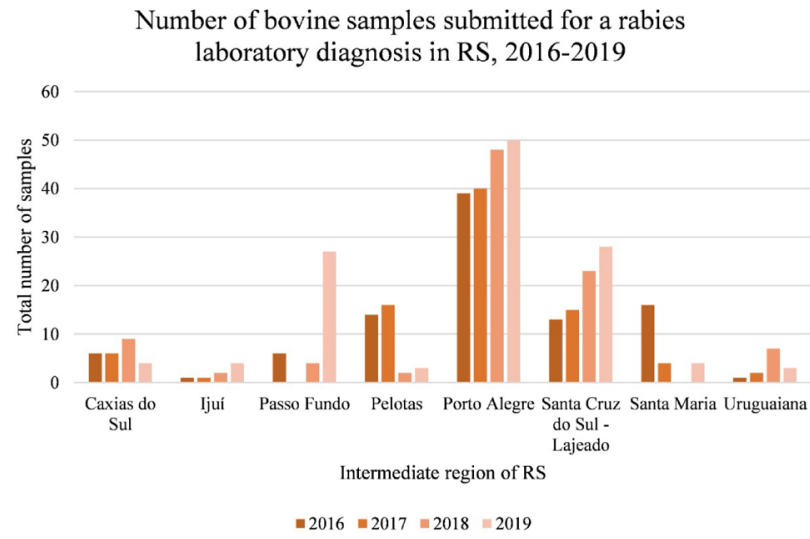

Figure 8. The number of bovine samples submitted for a laboratory diagnosis of rabies in each intermediate region of RS from 2016 to 2019.

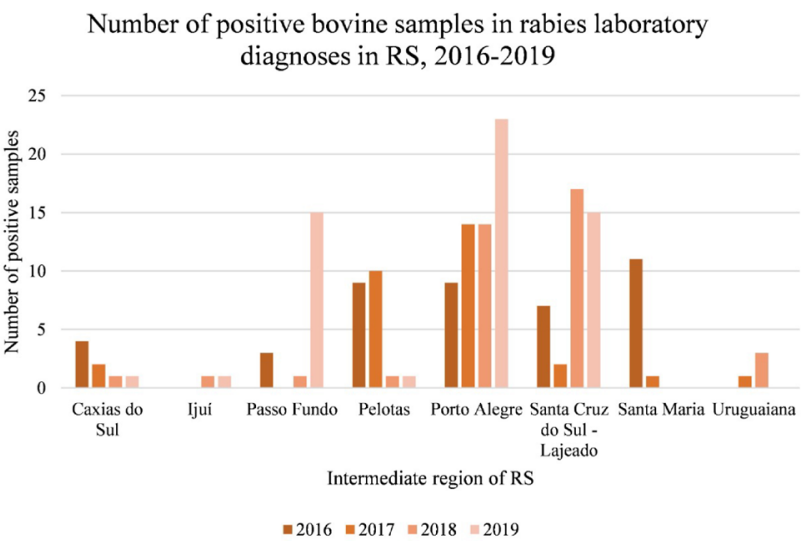

Figure 9. The number of positive bovine sample sent in for a laboratory diagnosis of rabies in each intermediate region of RS from 2016 to 2019.

comprehending longer periods should be performed to confirm seasonality findings and assess for rabies cyclicity in cattle.

Only two specimens of $D$. rotundus samples were sent in for a rabies diagnosis in 2019. Both results were negative. Cunha (2016) showed that the genus Desmodus was amongst the genera with the highest rates of diagnoses in RS, alongside Tadarida and Molossus. Nevertheless, the last positive sample of $D$. rotundus was registered in 2014. However, since the occurrence of bovine rabies has not decreased, the surveillance of bat populations must be improved.

Although insectivore and frugivore bats are also relevant in rabies epidemiology (BATISTA et al., 2009), the D. rotun$d u s$ bat is the primary source of infection in cattle and has been located in urban areas in Brazil (DANTAS-TORRES; 


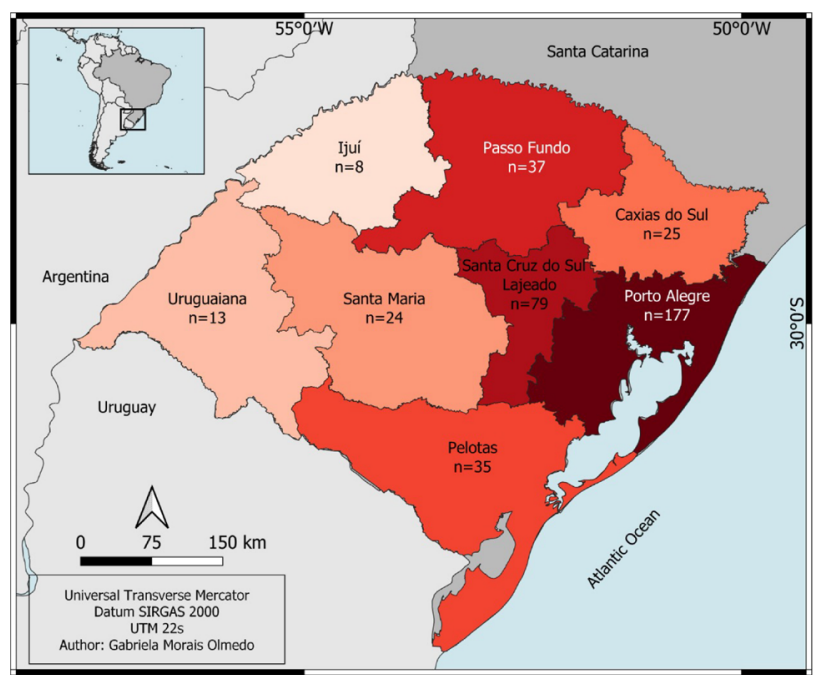

Figure 10. Total number of bovine samples submitted for a laboratory diagnosis of rabies from intermediate regions of RS.

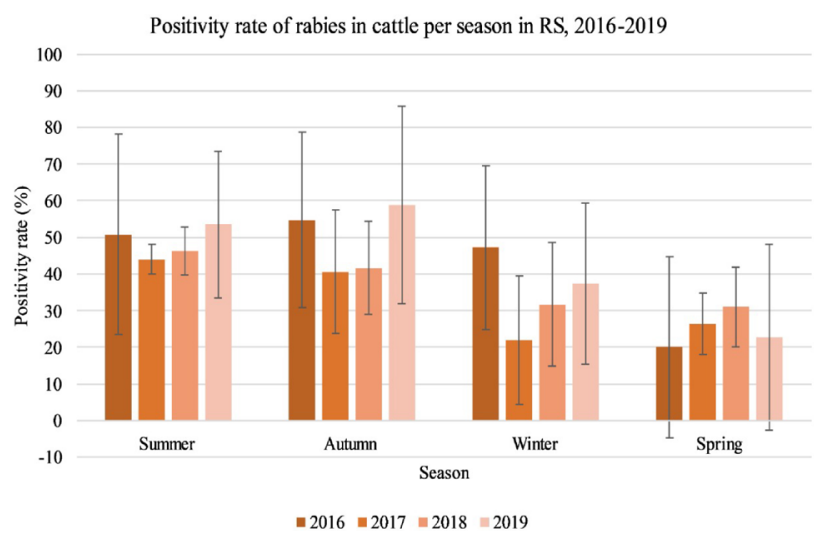

Figure 11. Rabies positivity rates in cattle per season in RS from 2016 to 2019.

VALENÇA; ANDRADE FILHO, 2005; ESBÉRARD et al., 2014; FERRAZ; ACHKAR; KOTAIT, 2007). Active surveillance is a valuable tool to improve sampling, fortify control measures, and monitor risks to public health in both rural and urban areas.
Besides this, studies regarding the ecology and biology of different bat species in RS are also important to help understand bovine rabies in the state. Another important issue to be considered concerns the poorly filled out request forms for herbivore rabies testing, as reported by Migliavacca et al. (2020). While the variable of the municipality was correctly filled out, geographic coordinates were poorly stated and several samples were sent in without a submission form. These lead to a lack of information that could be useful in identifying outbreaks and their relation to bat population dynamics in each region, among other associations.

Considering the large cattle populations in RS, it is important to enhance sampling practices in municipalities that have not been diagnosing rabies, especially in areas showing high numbers of cases, such as the Porto Alegre, Passo Fundo, and Santa Cruz do Sul - Lajeado regions. Furthermore, the lower number of samples sent in for laboratory diagnosis in the Ijuí, Santa Maria, and Pelotas regions in recent years, and the continually reduced sampling in Uruguaiana, should be evaluated to improve sampling practices and lower the risk of unknown local outbreaks.

\section{CONCLUSIONS}

Official numbers can be misleading because of the under-sampling of animals often seen in the field. It is important to provide adequate training to reinforce the sampling process, from sample submission to diagnosis, as this would provide more reliable data. In RS, each region faces different challenges that need to be thoroughly analyzed and considered in the decision-making process. Moreover, considering the seasonal occurrence of rabies, herd immunization must take place before the summer and autumn months. Active surveillance, especially of bat populations and under-sampled regions, must be strengthened to accurately estimate the impact of rabies.

\section{ACKNOWLEDGMENTS}

We would like to thank Gabriela Morais Olmedo for creating the maps.

\section{REFERENCES}

BATISTA, H. B. de C. R. et al. Canine rabies in Rio Grande do Sul caused by an insectivorous bat rabies virus variant. Acta Scientiae Veterinariae, v. 37, n. 4, p. 371-374, 2009.

CENTRO ESTADUAL DE VICILÂNCIA EM SAÚDE (CEVS). Raiva. 2020. Disponível em: <https:/www.cevs.rs.gov.br/raiva>. Acesso em: 10 nov. 2020.

CUNHA, D. L. B. W. M. da. Trinta e nove anos de diagnóstico de raiva em quirópteros no Rio Grande do Sul, Brasil (1976-2014).
2016. 85 f. Dissertação (Mestrado em Saúde Animal) - Instituto de Pesquisas Veterinárias Desidério Finamor, Eldorado do Sul, 2016.

DANTAS-TORRES, F; VALENÇA, C.; ANDRADE FILHO, G. V. de. First record of Desmodus rotundus in urban area from the city of Olinda, Pernambuco, Northeastern Brazil: a case report. Revista do Instituto de Medicina Tropical de São Paulo, v. 47, n. 2, p. 107-108, 2005. 
DEAN, D. J., ABELSETH, M. K., \& ATANASIU, P. The fluorescent antibody test. In: MESLIN, F. X.; KAPLHAN, M. M.; KOPROWSKI, $\mathrm{H}$. (Eds.). Laboratory Techniques in Rabies. Geneva: World Health Organization, 1996. p. 88-93.

DOCNANI, R. et al. Epidemiologia descritiva da raiva dos herbívoros notificados no estado do Paraná entre 1977 e 2012 . Pesquisa Veterinária Brasileira, v. 36, n. 12, p. 1145-1154, 2016.

ESBÉRARD, C. E. L. et al. Bats (Mammalia, Chiroptera) of an urban park in the metropolitan area of Rio de Janeiro, southeastern Brazil. Iheringia, Série Zoologia, v. 104, n. 1, p. 59-69, 2014.

FERNANDES, M. E. B et al. Rabies in humans and non-humans in Pará, the Brazilian Amazon. Brazilian Journal of Infectious Diseases, v. 17, п. 2, p. 251-253, 2013.

FERRAZ, C.; ACHKAR, S. M; KOTAIT, I. First report of rabies in vampire bats (Desmodus rotundus) in an urban area, Ubatuba, São Paulo state, Brazil. Revista do Instituto de Medicina Tropical de São Paulo, v. 49, n. 6, p. 389-390, 2007.

INSTITUTO BRASILEIRO DE GEOGRAFIA E ESTATÍSTICA (IBGE). Pesquisa Pecuária Municipal. Disponível em: <https:/www.bge. gov.br/estatisticas/economicas/agricultura-e-pecuaria/9107producao-da-pecuaria-municipal.html?=\&t=resultados $>$. Acesso em: 10 nov. 2020.

KOTAIT, I. et al. Controle da raiva dos herbívoros. São Paulo: Instituto Pasteur, 1998.

LIMA, E. F. et al. Sinais clínicos, distribuição das lesões no sistema nervoso e epidemiologia da raiva em herbívoros na região Nordeste do Brasil. Pesquisa Veterinária Brasileira, v. 25, n. 4, p. 250-254, 2005.

MICLIAVACCA, V. F. et al. Evaluation of data input in a rabies testing request form for herbivores. Arquivos do Instituto Biológico, v. 87, p. 1-5, 2020.

MORI, A. E.; LEMOS, R. A. A. Raiva. In: LEMOS, R. A. A. (Ed.). Principais Enfermidades de Bovinos de Corte do Mato Grosso do Sul: reconhecimento e diagnóstico. Campo Grande: Universidade Federal do Mato Grosso do Sul, 1998.

RIBAS, N. L. K. de S. et al. Doenças do sistema nervoso de bovinos no Mato Grosso do Sul: 1082 casos. Pesquisa Veterinária Brasileira, v. 33, п. 10, p. 1183-1194, 2013.

RIBEIRO, T. M. P et al. Casos notificados de raiva em bovinos na região norte do Brasil no período 2005-2017. Jornal Interdisciplinar de Biociências, v. 3, n. 1, 2018.

RIO DE JANEIRO. Secretaria de Estado de Saúde. Alerta Raiva 001/2020. Disponível em: <http:/www.riocomsaude.rj.gov.br/ Publico/MostrarArquivo.aspx?C=D2ZqI3xc158\%3D>. Acesso em: 10 nov. 2020.
RIO GRANDE DO SUL. Agricultura emite alerta sanitário para aumento de focos de raiva por herbívoros. 2019. Disponível em: <https:/www.estado.rs.gov.br/agricultura-emite-alerta-sanitariopara-aumento-de-focos-de-raiva-por-herbivoros>. Acesso em: 10 nov. 2020.

RIO GRANDE DO SUL. Secretaria da Agricultura, Pecuária e Desenvolvimento Rural. Departamento de Defesa Agropecuária. Seção de Epidemiologia e Estatística. Saldo bovinos 2016-2020. 2020. Disponível em: <https:/www.agricultura.rs.gov.br/see>. Acesso em: 17 nov. 2020.

RODENBUSCH, C. R. et al. Spatial and temporal description of laboratory diagnosis of bovine rabies in the state of Rio Grande do Sul, Brazil. Acta Scientiae Veterinariae, v. 44, 2016.

RODRICUES, E. D. L. et al. Prevalência de raiva animal no estado do Pará, no período de 2004 a 2013. Rev. Pan-Amazônica de Saúde, v. 9, ก. 4, p. 57-62, 2018.

ROSA, E. S. T. da et al. Bat-transmitted human rabies outbreaks, Brazilian Amazon. Emerging Infectious Diseases, v. 12, n. 8, p. 1197-1202, 2006.

SANTA CATARINA. Secretaria de Estado da Saúde. Santa Catarina registra primeiro caso de raiva humana em $\mathbf{3 8}$ anos. Disponível em: <https:/www.saude.sc.gov.br/index.php/noticias-geral/ todas-as-noticias/1641-noticias-2019/10628-santa-catarinaregistra-primeiro-caso-de-raiva-humana-em-38-anos>. Acesso em: 12 nov. 2020.

SANTOS, A. V. P et al. Raiva em herbívoros no estado do Piauí no período de 2007 a 2011 . Acta Veterinaria Brasilica, v. 10, п. 3, p.224-228, 2016.

SILVA, J. A et al. Distribuição temporal e espacial da raiva bovina em Minas Gerais, 1976 a 1997. Arquivo Brasileiro de Medicina Veterinária e Zootecnia, v. 53, n. 3, 2001.

TEIXEIRA, T. F. et al. Diagnóstico de raiva no Rio Grande do Sul, Brasil, de 1985 a 2007. Pesquisa Veterinária Brasileira, v. 28, ก. 10, p. 515-520, 2008.

VARGAS, A; ROMANO, A. P. M.; MERCHÁN-HAMANN, E. Human rabies in Brazil: a descriptive study, 2000-2017. Epidemiologia e Serviços de Saúde, v. 28, n. 2, p. 1-7, 2019.

VELASCO-VILLA, A. et al. The history of rabies in the Western Hemisphere. Antiviral Research, v. 146, p. 221-232, 2017.

WADA, M. Y.; ROCHA, S. M.; MAIA-ELKHOURY, A. N. S. Situação da raiva no Brasil, 2000 a 2009. Epidemiologia e Serviços de Saúde, v. 20, n. 4, p. 509-518, 2011.

WORLD ORGANIZATION HEALTH (WHO). Laboratory techniques in rabies, volume I. 5. ed. Genebra: World Health Orgonalization, 2018. 304p. 